\title{
Rival Powers, Rival Images: Diocletian's Palace at Split in Light of Sasanian Palace Design
}

\author{
Anne Hunnell Chen
}

It is well known that the third century AD saw intense and prolonged conflict between the Romans and their eastern neighbors, the Sasanian Persians. ${ }^{1}$ What has often remained unrecognized, however, is the Roman court's poignant use of visual media - both architectural and iconographical — to counter Sasanian claims of superiority on the world stage in this period. ${ }^{2}$ In particular, a significant parallel between the ideologically charged palatial spaces built in the two realms has remained overlooked due in large part to our conditioned way of viewing the fortified imperial palaces that began to appear in the eastern part of the Roman Empire in the late third century.

Entrenched ideas about one of the touchstone monuments of the late Roman period, Diocletian's palace at Split, located on the modern Croatian coast, have shaped the discussion of comparable, contemporary imperial residences discovered in the last forty years at Šarkamen and Gamzigrad in eastern Serbia. For this reason, a fresh look at Diocletian's palace, informed by new archaeological data and a theoretical approach sensitive to inter- and transcultural perspectives, is necessary. Consideration of the Split residence with reference to comparanda both inside and outside the Roman Empire reveals that the design choices made in Roman palaces from the late third and early fourth centuries AD were part of a concerted effort on the part of late Roman

1 Matthew P. Canepa, The Two Eyes of the Earth: Art and Ritual of Kingship Between Rome and Sasanian Iran (Berkeley, 2009); Jan Willem Drijvers, "Rome and the Sasanid Empire: Confrontation and Coexistence," in A Companion to Late Antiquity, eds. Philip Rousseau and Jutta Raithel (Chichester, 2009), 441-454; Beate Dignas and Engelbert Winter, Rome and Persia in Late Antiquity: Neighbours and Rivals (Cambridge, Eng., 2007); Alice Landskron, Parther und Sasaniden: das Bild der Orientalen in der römischen Kaiserzeit, (Wien, 2005); A.D. Lee, Information and Frontiers: Roman Foreign Relations in Late Antiquity (Cambridge, Eng., 1993).

2 Matthew Canepa's recent volume, The Two Eyes of the Earth, is the exception, and has been foundational in the exploration of competitive cultural exchange between rival courts in the Late Roman and Byzantine Empires and the Sasanian east. 
emperors to render their power legible to an international host of officials both at home and abroad.

\section{Diocletian's Palace and Military Architecture}

The emperor Diocletian came to power in the year $284 \mathrm{AD}$. A respected military leader in the Roman offensive against the Sassanid Persians of the $280 \mathrm{os}$, Diocletian's fellow soldiers raised him to the rank of ruler following discovery of the reigning emperor's murder on the march back from the army's eastern mission. ${ }^{3}$ Diocletian is perhaps most famous, however, for his innovative decision in $293 \mathrm{AD}$ to share the responsibility of governing and protecting the vast Roman Empire along with three other colleagues, thereby initiating the unique political arrangement that modern scholars call the Tetrarchy. ${ }^{4}$

The military origins of Diocletian and his co-rulers routinely color the interpretation of all things Tetrarchic: from portrait style to architectural and iconographic choices. It is no surprise, then, that Diocletian's palace at Split, a monument deemed as emblematic of the Tetrarchic period owing no doubt to its excellent state of preservation and storied history of excavation and publication dating back to the ${ }^{17}$ th century, ${ }^{5}$ is framed in the literature first and

3 For an account of the events and chronology surrounding Diocletian's first years in power, see Alan K. Bowman, "Diocletian and the First Tetrarchy," in Cambridge Ancient History 12, eds. Alan Bowman, Averil Cameron, and Peter Garnsey (Cambridge, Eng., 2005), 69-70; John Drinkwater, "Maximinus to Diocletian and the Crisis" in Cambridge Ancient History 12, eds. Alan Bowman, Averil Cameron, and Peter Garnsey (Cambridge, Eng., 2005), 58-6o; David S. Potter, The Roman Empire at Bay, AD 180-395 (London, 2004), 280-281; Andre Chastagnol, "Maximien Hercule à Rome" in Aspects de l'antiquité tardive: Saggi di storia antica, ed. A. Chastagnol and I. Tantillo (Rome, 1994), 24; Timothy David Barnes, The New Empire of Diocletian and Constantine (Cambridge, Eng., 1982), 30-2.

4 Debate persists over whether or not the creation of a four-man division of power was part of a mastermind plan for governmental administration put into place in a gradual series of steps over a number of years, or a power-sharing solution formulated as the result of ad-hoc decisions made to solve problems that arose in the course of Diocletian's reign. For a major proponent of the former, see Frank Kolb, Diocletian und die Erste Tetrarchie: Improvisation oder Experiment in der Organisation monarchischer Herrschaft? (Berlin, 1987); Frank Kolb, "La Tétrarchie: Chronologie und Ideologie der Tetrarchie," Antiquité Tardive 3 (1995), 21-31. For the latter view, see W. Seston, Diocletian et la Tetrarchie (Paris, 1946).

5 Palladio made drawings of parts of the palace in the 16th century and Spon and Wheler gave an eyewitness account of the palace remains in the late 17th century. In the 18th century, both Farlati and Adam wrote on the Split structures. Engagement with the site accelerated in the 19th and early 2oth centuries with surveys and detailed descriptions published by Lanza, Niemann, Hebrard, Zeiller, and Bulić. For discussion of the history of research at the palace 
foremost with regard to its militaristic resemblance. Whether seen in plan from above or approached on foot via one of the complex's three gates, the use of military-inspired features in the Split palace is undeniable (Figs. 11.1-11.2).

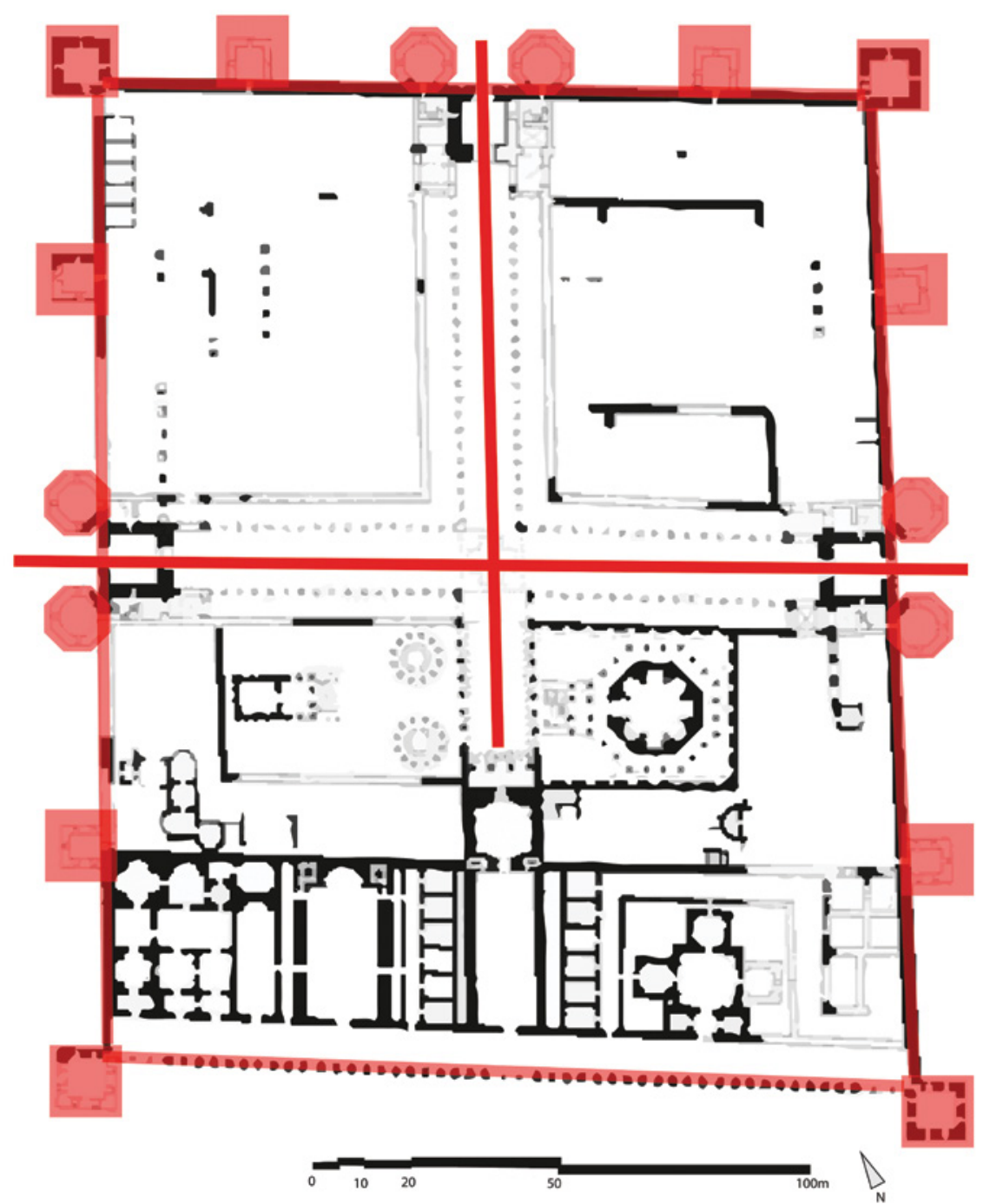

FIGURE 11.1 Plan of Diocletian's Palace at Split, highlighting the main north-south and east-west roads, towers and fortress walls.

PLAN ADAPTED FROM ĆURČIĆ, 2010.

see Tomislav Marasović, "Diciassette secoli di ricerche e restauri nel palazzo di Diocleziano a Spalato," in Diocletian, Tetrarchy and Diocletian's Palace on the 17ooth Anniversary of Existence, eds. N. Cambi, J. Belamarić, and T. Marasović (Split, 2009), 15-49. 


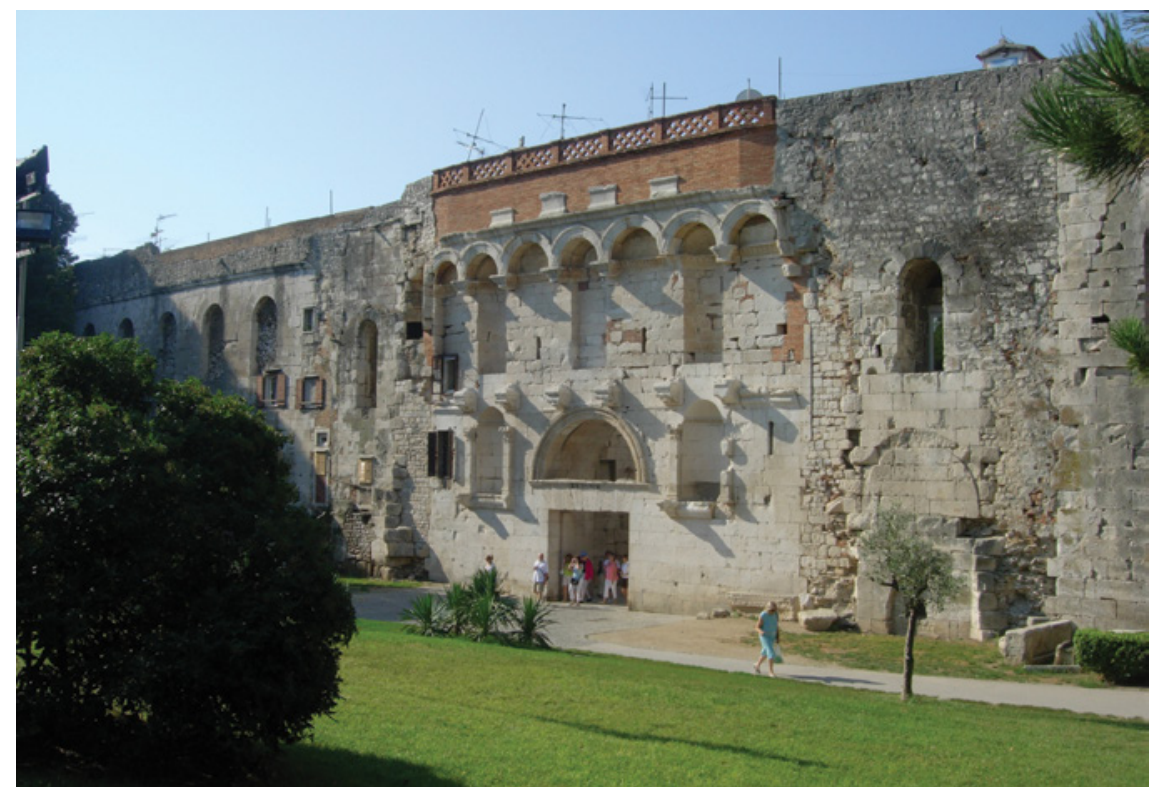

FIGURE 11.2 The North “Golden" Gate. Diocletian's palace, Split.

PHOTOGRAPH COURTESY OF SAMULI LINTULA; CREATIVE COMMONS ATTRIBUTION SHAREALIKE 3.0.

Immediately striking are the fortress-like walls punctuated with octagonal gate towers and rectangular intermediary towers that encircle the entirety of the complex. Beyond Split's curtain wall, other features of the complex likewise point to military derivation. Propugnaculi, the square rooms placed directly after the gates leading into the Split complex, served in Roman fortress design to stall besiegers in the event they breeched gate defenses. ${ }^{6}$ Inside the walls, the symmetrical organization of space around a main north-south and east-west road is yet again closely paralleled in the layouts of Roman military camps. It is precisely because Diocletian's palace adopted such features into its design that it was originally studied primarily among examples of military rather than palatial architecture. ${ }^{7}$

6 A.J. Brothers, "Diocletian's Palace at Split," Greece and Rome 19, no. 2 (1972): 185.

7 Slobodan Ćurčić, Architecture in the Balkans from Diocletian to Süleyman the Magnificent (New Haven, 2010), 26; Inge Uytterhoeven, "Housing in Late Antiquity: Thematic perspectives," in Housing in Late Antiquity. From Palaces to Shops, ed. Luke Lavan, et al. (Leiden, 2007), 34; Noël Duval, "La place de Split dans l'architecture aulique du Bas-Empire" Urbs 4 (1961), 67-95; J.J. Wilkes, Diocletian's Palace, Split: Residence of a Retired Roman Emperor (Sheffield, 1993), 69-71; R. Fellmann, "Der Diokletianspalast von Split im Rahmen der spätrömischen Militärarchitektur," Antike Welt 10 (1979), 47-55. 
Despite the inclusion of components clearly culled from the martial realm, the specifics of the palace's placement and design confirm that the complex never served an overt military function. For instance, the palace stood in a definitively non-combat zone. Placed in a quiet coastal area removed from both the troubled eastern and western fronts, the Split palace was sited on low ground although a number of higher-and thus more defensible-locales were available in the immediate vicinity. Even the towers included in the curtain wall were probably more for show than for practical use. The intermediary and corner towers at Split were rectangular, a shape no longer preferred in contemporary defensive design; by this date Roman military engineers had determined that towers with rounded profiles held more tactical advantage, especially at vulnerable corner positions. ${ }^{8}$ Recent excavations in the palace's northern sector have also yielded no sign of the barracks buildings researchers expected to find. ${ }^{9}$

It is based on the use of defensive architectural components in a predominantly non-martial structure and the site's inclusion of spaces gradated from public to private that the residence at Split is generally regarded as a hybridization of military and villa construction. This unique combination is usually chalked up to some imagined nostalgia on the part of Diocletian since he came to imperial office by way of the military ranks. ${ }^{10}$ While there is value in the

8 On military camp design and tower shapes, see James Lander, Roman Stone Fortifications. Variation and Change From the First century A.D. to the Fourth, BAR international series (Oxford, Eng. 1984), 304-5; Gregory Shelagh, Roman Military Architecture on the Eastern Frontier, 3 vols. (Amsterdam, 1995), 162-3.

9 On the excavations in the northern sector and the possible presence of a gynaeceum in this area, see K. Marasović and J. Marasović, S. Perojević, "Istrazivanja Dioklecijanove palače od 1985. do 2005. godine [The Research of Diocletian's Palace from 1985 to 2005]" in Diocletian, Tetrarchy and Diocletian's Palace on the 17ooth Anniversary of Existence, ed. N. Cambi; J. Belamarić; and T. Marasović (Split, 2009), 51-94; J. Belamarić, "Gynaeceum Iovense Dalmatiae. Aspalatho," in Diokletian und die Tetrarchie. Aspekte einer Zeitenwende, eds. Alexander Demandt, Andreas Golz, and Heinrich Schlange-Schöningen (Berlin, 2004); J. Belamarić, "The Date of Foundation and Original Function of Diocletian's Palace at Split," Hortus Artium Medievalium 9 (2003), 173-185.

10 See for instance Wolfgang Kuhoff, "Das Tetrarchische Herrschaftssystem und seine Darstellung in der Architektur: Herrscherresidenzen und Altruhesitze als Ausdruck Kaiserlicher Regierung und Repräsentation," in Diocletian, Tetrarchy and Diocletian's Palace on the 17ooth Anniversary of Existence, eds. N. Cambi, J. Belamarić, and T. Marasović (Split, 2009), 107-115; Ramsay MacMullen, Soldier and Civilian in the Later Roman Empire (Cambridge, Massachusetts, 1963), 42-6. Strzygowski's work is an exception; he recognized similarities with Roman camp design, but held that the urban planning of such eastern Roman cities as Antioch and Phillipopolis impacted the ultimate design for 
military comparisons, focus on the site's martial parallels has long dominated our viewing and, consequently, shaped our understanding of the palace.

\section{$2 \quad$ Fortified Palaces at Gamzigrad and Šarkamen}

The recent identification of a contemporary palace, also located on the Balkan Peninsula and belonging to one of Diocletian's imperial colleagues, provides new evidence that suggests the expedience of expanding the frame of reference for these Late Roman palaces beyond the Roman borders. With the 1984 discovery of an inscription containing the topographical name 'Felix Romuliana,' (Fig. 11.3) scholars identified a fortified structure near the Serbian village of Gamzigrad as an imperial palace built by Diocletian's Tetrarchic co-ruler, Galerius (Fig. 11.4). ${ }^{11} \mathrm{~A}$ third, unfinished fortified complex near the Serbian village of Šarkamen (Fig. 11.5) that is likewise tentatively connected with yet another Tetrarch, ${ }^{12}$ points towards a trend in imperial architecture under the Tetrarchic reign.

As at Diocletian's palace, a massive military-inspired curtain wall surrounds the complex at Romuliana and showcases a series of towers designed above all to make an impression: the enormous girth of Romuliana's towers offered no defensive advantage and instead communicated the grandeur of the complex

Diocletian's palace in Split. See J. Strzygowski, "Spalato, ein Markstein der romanischen Kunst bei ihrem Ubergange vom Orient Bach dem Abendlande," in Studien aus Kunst und Geschichte; Friedrich Schneider zum siebzigsten Geburtstage gewidmet von seinen Freunden und Verehrer, ed. Joseph Saner (Freiburg im Breisgau, 1906), 323-336.

11 On the inscription, its importance for the identification of the site and the location of its original display, see Maja Živić, "Artistic Achievements in the Imperial Palace," in Felix Romuliana Gamzigrad, ed. Ivana Popović (Belgrade, 2012), 101-2; Maja Živić, Felix Romuliana 50 Years of Solving (Belgrade, 2003), 21-5 and cat. 1; Emanuel Mayer, Rom ist dort, wo der Kaiser ist. Untersuchungen zu den Staatsdenkmälern des dezentralisierten Reiches von Diocletian bis zu Theodosius II (Mainz, 2002), 80-90; Dragoslav Srejović, Petar Petrović, and Veselin Kostić, Roman Imperial Towns and Palaces in Serbia (Belgrade, 1993), 49, 204-5, cat. 48 .

12 The Šarkamen complex is attributed to Maximinus Daia based on its similarity with the palace of Galerius at Romuliana, his familial connection to the region (for sources, see Barnes, New Empire: 39), the fragments of a large-scale seated porphyry statue (comparable to the seated statue of a Tetrarch from the Greco Roman Museum of Alexandria, inv. \#5954), and the presence of gold plaques with the impressions of Tetrarchic imperial portraits taken from coins. The most recent overview of the site published in English is Miodrag Tomović, et al, Šarkamen. A Tetrarchic Imperial Palace, The Memorial Complex (Belgrade, 2005). 


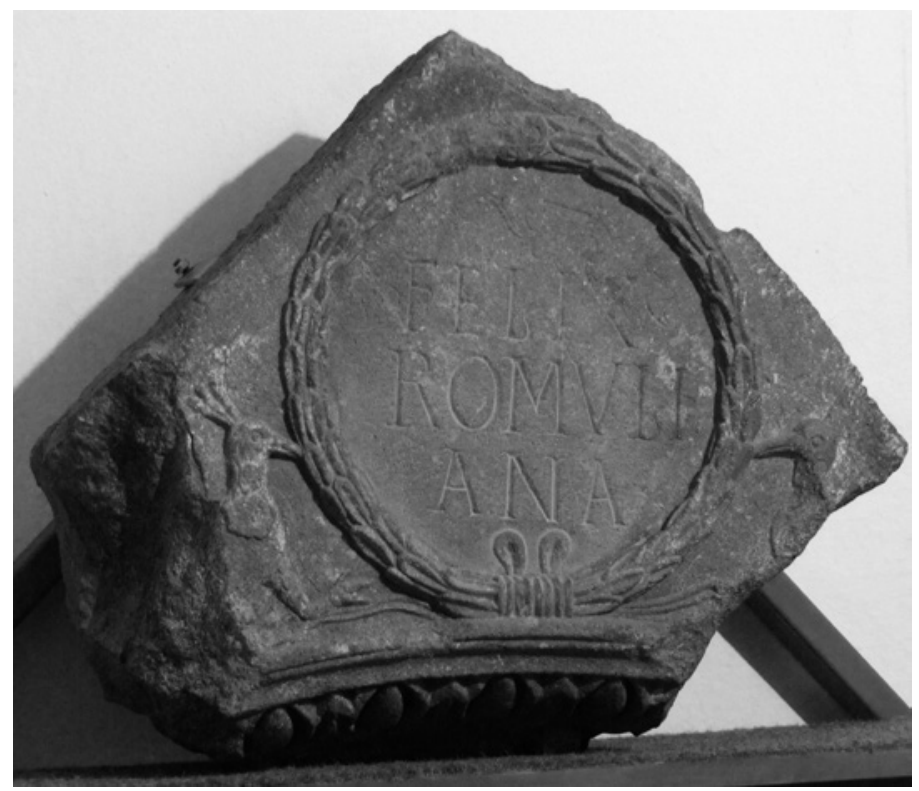

FIGURE 11.3 "Felix Romuliana" inscription excavated at the Late Roman palace near Gamzigrad, Serbia.

PHOTOGRAPH COURTESY OF THE NATIONAL MUSEUM, ZAJEČAR.

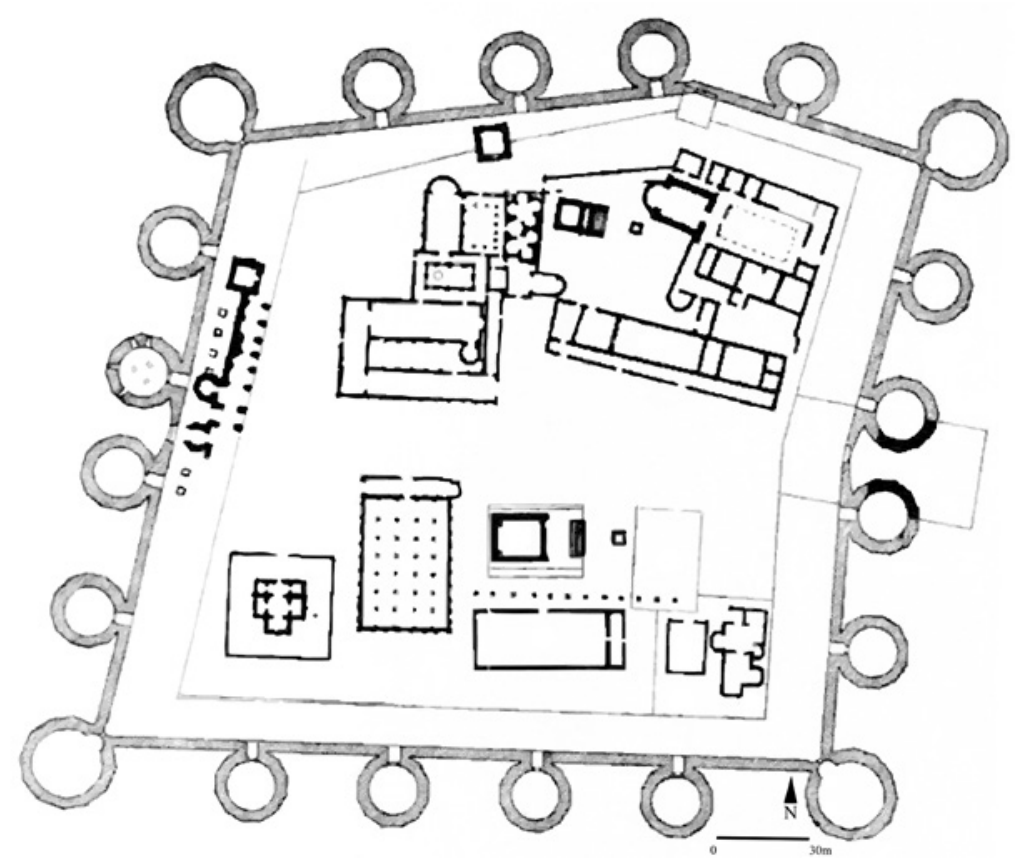

FIGURE 11.4 Plan of the Late Roman palace near Gamzigrad, Serbia. PLAN ADAPTED FROM ĆURČIĆ, 2010. 


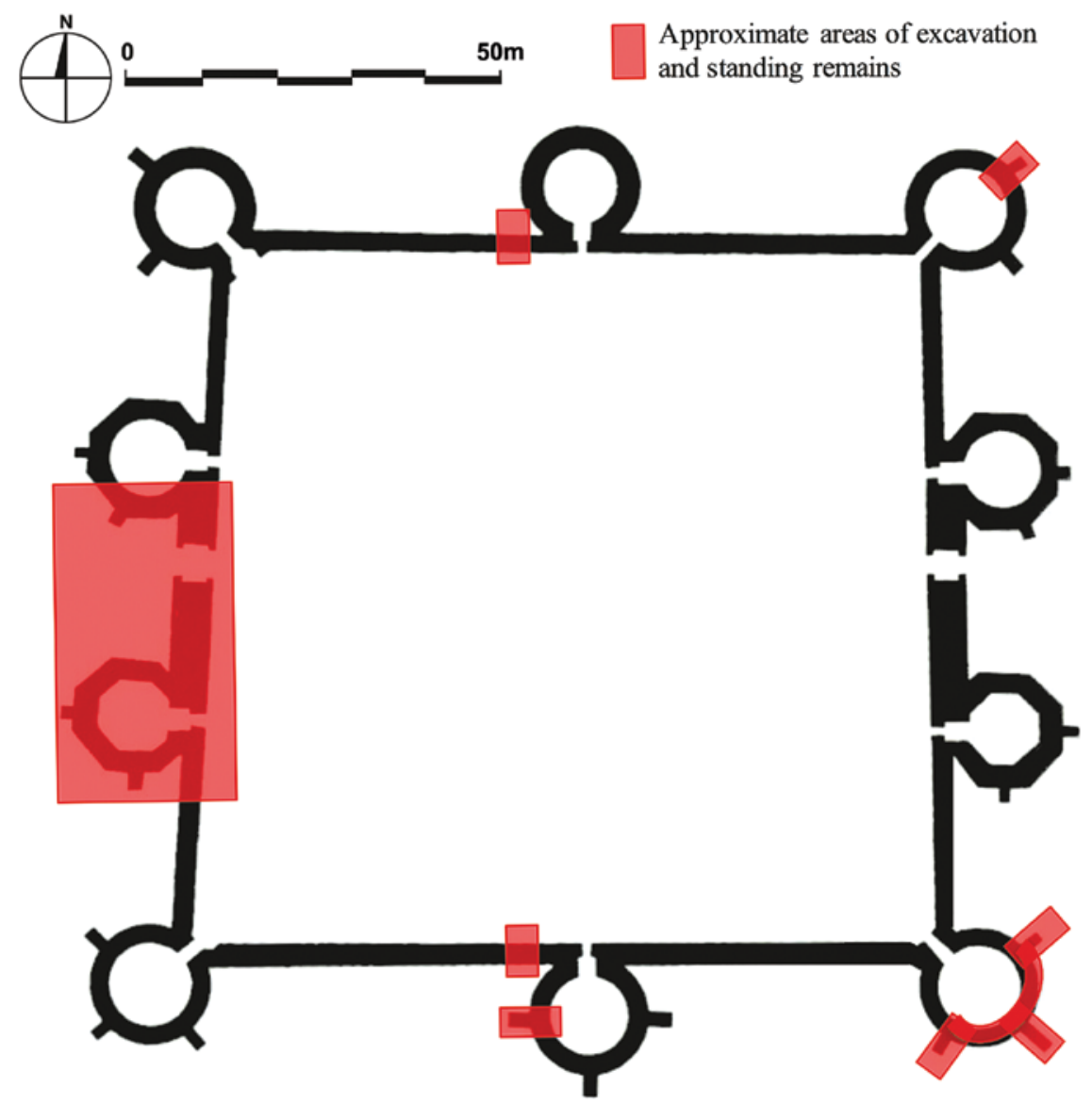

FIGURE 11.5 Plan of the unfinished curtain wall from the Late Roman complex discovered near the village of Šarkamen in eastern Serbia.

PLAN ADAPTED FROM ĆURČIĆ, 2010.

they screened. ${ }^{13}$ Likewise comparable is the physical positioning of the two palaces-like at Split, the palace at Romuliana is removed from barbarian threat and situated on low ground despite the proximate availability of more defensible alternatives.

Prior to the period of the Tetrarchy, the idea of placing an imperial residence within massive fortifications was unprecedented in Roman architecture. The archetypal Roman palace, the Palatine complex in Rome, was designed to

13 The intermediate towers at Romuliana measure approximately 25 meters in diameter; those at the fortification's corners measure approximately 30 meters in diameter. Ćurčić, Architecture in the Balkans, 24. 
maintain the fiction of the emperor's accessibility to his subjects. Its central location, intimate connection with the Circus Maximus, incorporation of public sanctuaries, and eschewal of its own separatist fortification wall all worked toward a publically inclusive effect. In contrast, Split and Romuliana, with their rural locations, monumental walls, and lack of entertainment venues for the benefit of the greater public such as theaters, amphitheaters, or circuses, visually communicated the restriction of access to the emperor. ${ }^{14}$ As such, the Palatine clearly does not stand as the primary conceptual reference point for the fortified palaces of the late third century. The Hellenistic precedents upon which the Palatine drew likewise turn up empty in this regard. Palaces at Vergina, Pella, Alexandria, and Pergamon share the characteristic that they are designed to communicate a degree of pubic inclusiveness given their incorporation of sanctuaries and entertainment venues. Even those palaces of the Hellenistic period that featured fortress walls as part of their design, such as the Hellenistically inspired Thracian palace at Seuthopolis, or the Attalid palace at Pergamon, differ from the Roman palaces of the third century AD in that the fortifications at such sites, given their location in disputed territories, served a definite defensive purpose in contrast to the more symbolically motivated defensive systems at the Tetrarchic structures. Moreover, it is significant that although the Romans no doubt knew the residence at Peragmon, they chose not to incorporate fortifications into their palace design until a full five centuries after the foundation of the Attalid royal residence. The lack of directly comparable Roman or Hellenistic precedents has therefore set the task of determining what prompted this noticeable shift in imperial architectural design under the Tetrarchy. There must have been some motivating factor at this particular historical moment to prompt a break from three centuries worth of Roman precedents (and preceding generations of Hellenistic exempla upon which they drew) with regard to royal palace design. It is to this end that the 'military nostalgia' interpretation has been deployed.

However, archaeological finds from Romuliana weighed together with the potential for bi-directionality in cultural influence between Rome and her eastern rivals that scholars such as Matthew Canepa and Lynne Lancaster have recently illustrated, ${ }^{15}$ may suggest another route of inquiry for the Roman fortified palaces. Among the finds from Romuliana's ongoing excavations are bricks stamped in the name of the fifth Macedonian legion, a unit whose presence is

\footnotetext{
14 Ibid., 32-6.

15 Canepa, Two Eyes of the Earth; Lynne Lancaster, "Parthian Influence on Vaulting in Roman Greece? An Inquiry into Technological Exchange Under Hadrian," American Journal of Archaeology 114, no. 3 (2010), 447-472.
} 


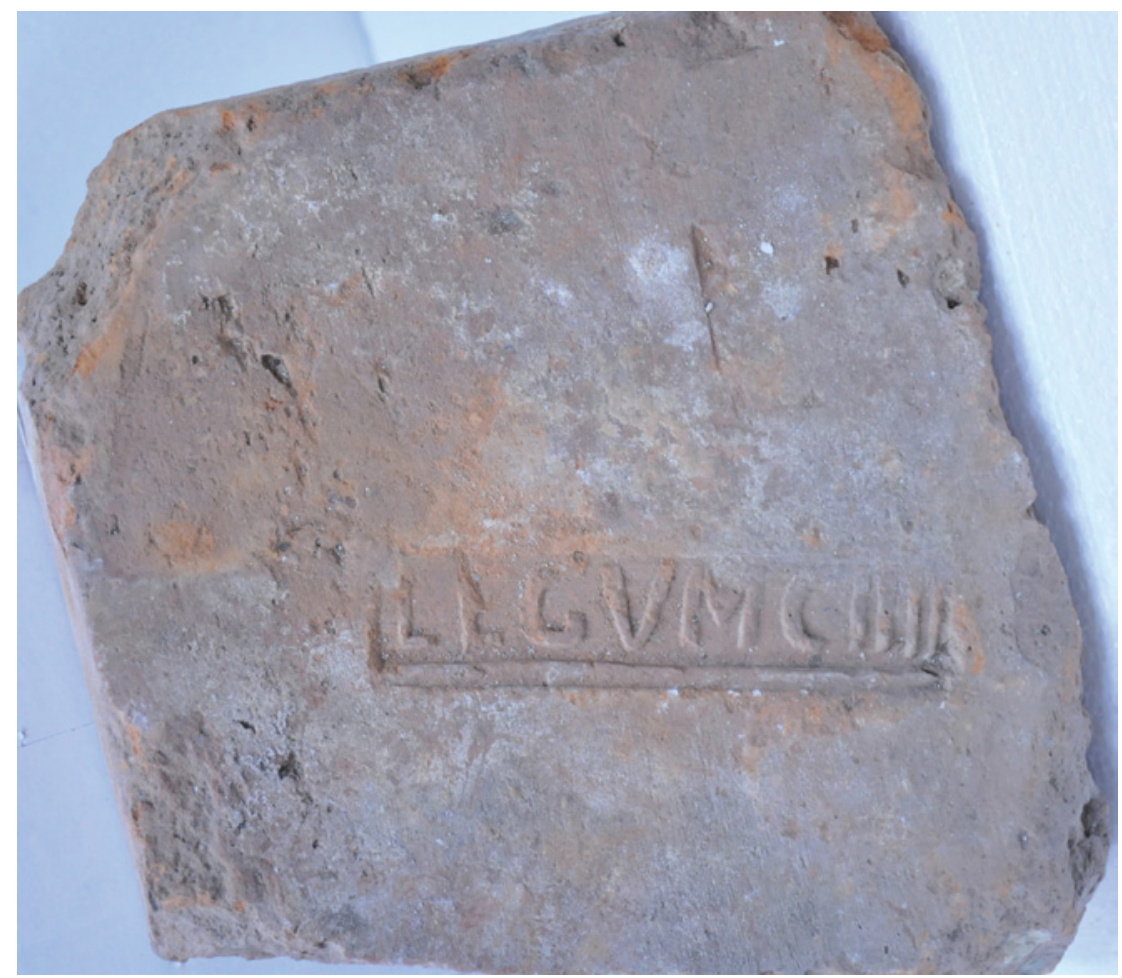

FIGURE 11.6 Brick stamped in the name of the Fifth Macedonian legion. From the Late Roman palace near Gamzigrad, Serbia.

PHOTOGRAPH COURTESY OF THE NATIONAL MUSEUM, ZAJEČAR.

attested deep in the territory of the Persian Sasanids in the years directly preceding the palace's construction (Fig. 11.6). These stamps offer a terminus post quem of winter 298/299 AD, the date at which hostilities with the Sasanians were concluded, and imply that this legion, newly returned home with exposure to a world beyond the eastern borders of the Roman Empire, participated in the construction of Galerius' palace. ${ }^{16}$ The involvement of this legion also implies that the construction of the palace did not begin until the emperor Galerius - who himself commanded the legions on the Sasanian campaignreturned victorious to Roman territory after a martial tour in Persia.

16 M. Čanak-Medić, Gamzigrad: Kasnoantička palata: arhitektura i prostorni sklop [Gamzigrad: Late Antique Palace: Architecture and Spatial Organization] (Belgrade, 1978), 227; Maja Živić, “The Eternal Palace of Galerius," Minerva 18, no. 2 (2007), 32. 
The Romuliana brick stamps call our attention to some unrecognized historical parallels regarding the construction of Diocletian and Galerius' palaces that may in turn recommend comparison between the Tetrarchic fortified palaces and the Sasanian imperial residences in the east. Although confirmation of the exact dates of construction will have to await further archaeological work at both Split and Romuliana, clues from contemporary written sources, archaeology, iconography, and architecture suggest that both sites date relatively late in the collective reign of Diocletian and his colleagues. ${ }^{17}$ That is, it is probable that the construction of both palaces dates to after the decisive Roman defeat of the Sasanians that led to the Treaty of Nisibis of $299 \mathrm{AD}$, an armistice heavily favoring the Romans that prevented further major hostilities between the two empires until the mid fourth century. ${ }^{18}$

Similarly intriguing is the fact that three of the Tetrarchic colleaguesincluding the two who built the residences at Split and Romuliana-were at various times on Persian soil and even in the vicinity of the Sasanian capital city of Ctesiphon. Diocletian and Maximian participated in the capture of Ctesiphon in the 280 s, and Galerius advanced on the same city while successfully campaigning against the Persians in the late $290 .^{19}$ It is certain that the Sasanian capital city contained a palace in the third century, but because the extraordinary remains of its sixth-century successor occupy the site today, its exact characteristics have yet to be archaeologically determined. ${ }^{20}$

17 On the date of Romuliana see Živić "Artistic Achievements"; Živić, Felix Romuliana, 10-45; Mayer, Rom ist dort, 80-90. On the date of the palace at Split, see most recently G. Nikšić, "Diocletian's Palace-Design and Construction," in Bruckneudorf und Gamzigrad:spätantike Paläste und Großvillen im Donau-Balkan-Raum, ed. Gerda v. Bülow und Heinrich Zabehlicky (Bonn, 2011), 187-202.

18 The main primary source on the Treaty of Nisibis is Peter the Patrician, fragments 13-14. For a summary of other sources on the treaty, see Engelbert Winter, Die Sāsānidischrömischen Friedensverträge des 3. Jahrhunderts n. Chr. ein Beitrag zum Verständnis der aussen politischen Beziehungen zwischen den beiden Grossmächten (Frankfurt am Main, 1988), 169-71. For general discussion of the Treaty of Nisibis and its terms, see R.N. Frye, "The Political History of Iran Under the Sasanians," in The Cambridge History of Iran. The Seleucid, Parthian and Sasanian Periods, ed. Ehsan Yarshater (Cambridge, 2000), 130-1; Dignas and Winter, Rome and Persia, 122-31.

19 For a summary of the military careers of Diocletian, Maximian, and Galerius, see Barnes, New Empire, 30-8.

20 Most scholars now agree on the sixth-century date of the palace today standing at the site of ancient Ctesiphon, but some originally believed the building to date to the reign of Shapur I in the third century; see Remy Boucharlat, "Larchitecture sassanide," in Les Perses sassanides: Fastes d'un empire oublié (224-642), ed. F. Demange (Paris, 2006), 46-50; 
A sole early third-century relief that preserves a representation of the Ctesiphon palace is the only evidence for the appearance of the structure the Tetrarchic emperors would have seen while on campaign in the city. ${ }^{21}$ Fortunately, early Sasanian palaces subscribed to a rather standardized model of organization and construction. Other third-century Sasanian palaces and the Parthian predecessors on which they drew remain extant, and thus allow for comparisons with the Roman west. Taking into account that fortified palaces only came into existence in the eastern Roman provinces under emperors who had themselves campaigned in Persia and after the most decisive Roman victory of the century against their Sasanian nemesis, it is worth considering that Persian palatial architecture was one among a medley of elements that influenced the design of the palaces built under the Tetrarchy.

This is, of course, not to discount Hellenistic and Roman influences altogether. Much of the architectural vocabulary used in the Tetrarchic palaces is overtly Roman, as the columnar orders bear witness, and as already acknowledged, inspirations from military camp design played a part in the formal appearance of these palaces. Rather, the point is to enrich the narrative by exposing additional realms from which these late Roman rulers may have drawn inspiration, and to offer productive ideas beyond the 'military nostalgia' explanation to account for the sudden appearance of fortified imperial residences in non-combat areas under Diocletian and his colleagues. Inge Nielson has stressed in recent research highlighting the hybrid Macedonian, Egyptian, and Achaemenid roots of Hellenistic palaces, that "eastern models for palaces ... are typically overlooked in favor of Greek models." ${ }^{22}$ In an effort to avoid such bias with respect to Roman palaces, comparison with contemporary Persian palace architecture is in order, particularly given Roman tendency toward eclectic appropriation even from those they considered enemies (a point discussed further below), the close contact with the Persians at the time the Tetrarchic palaces appeared, and the enormous time-gap between the construction of the most comparable of the Hellenistic palaces and the residences at Split, Romuliana, and Šarkamen.

D. Huff, "Architecture sassanide," in Splendeur des Sassanides. L'empire perse entre Rome et la Chine, 224-642 (Brussels, 1993), 45-61. For a discussion of the dating, see Edward J. Keall, "Ayvan-e Kesra" in Enclopaedia Iranica vol. 3 (1987), 155-159.

21 Richard Brilliant, The Arch of Septimius Severus in the Roman Forum (Rome, 1967), 214-5.

22 Inge Nielsen, Hellenistic Palaces: Tradition and Renewal (Aarhus, 1994), 99. See also Inge Nielson (ed.), The Royal Palace Institution in the First Millenium BC: Regional Development and Cultural Interchange Between East and West (Athens, 2001). 


\section{Sasanian Palace Design and Spatial Organization at Split}

It turns out that the practice of situating imperial palaces within impressive fortification walls at a remove from cities-while without precursors in the Roman Empire-was a feature of early Sasanian architectural tradition that was itself likely inspired by preceding Parthian practices. Fortified palaces predating those constructed under the Tetrarchs in the eastern Roman Empire are known in the Parthian palace at Old Nisa and the Sasanian palace Qal'a-ye Doktar. ${ }^{23}$ What is more, in the case of the palace at Old Nisa excavators have yet to find any indication that the palace's fortifications served any real defensive, military function. Instead, the curtain walls surrounding the site were constructed for primarily symbolic and aesthetic reasons. ${ }^{24}$ This suggests that not only was the idea to hem a palace inside military-inspired walls already extant in the Near East before the Tetrarchic rise to power, but so too was the concept of using such walls primarily as symbolic statements of power rather than defensive features - a state of affairs thus comparable with the later Roman manifestations at Split, Romuliana, and Šarkamen, and in stark contrast to those much earlier militaristically motivated western examples at sites such as Seuthopolis.

Looking to the palace at Split with this new possibility in mind, a comparison between the spatial organization of Diocletian's palace and the recurring layout that is a defining feature of Sasanian palaces reveals surprising conceptual similarities (Fig. 11.7).

23 For the Parthian palace of Old Nisa see, A. Invernizzi "New Archaeological Research in Old Nisa," in The Art and Archaeology of Ancient Persia: New Light on the Parthian and Sasanian Empires, eds. Robert Hillenbrand, V.S. Curtis, and J.M. Rogers (London, 1998), 8; Dietrich Huff, "Formation and Ideology of the Sasanian State in the Context of Archaeological Evidence," in The Sasanian Era, eds. V.S. Curtis and S. Stewart (New York, 2008), 41-2. For the palace of Ardashir I at Qala-ye Doktar, Firuzabad, see Dietrich Huff and Philippe Gignoux, "Ausgrabungen auf Qal'a-ye Dukhtar bei Firuzabad 1976," Archäologische Mitteilungen aus Iran, Neue Folge 11 (1978); Dietrich Huff, "Qala-ye Dukhtar bei Firuzabad: Ein Beitrag zur sasanidischen Palastarchitektur,"Archäologische Mitteilungen aus Iran, 4 (1971); Dietrich Huff, "Formation and Ideology," 42-4; Dietrich Huff, "Qal'a-ye Doktar," Encyclopaedia Iranica (2006), <http://www.iranicaonline.org/articles/qala-ye-doktar>; Dietrich Huff, "Architecture sassanide," 50-3; Dietrich Huff, "Architecture III: Sasanian Periods," in Encyclopaedia Iranica vol. 2 (1986), 329-334; Dorothy Shepherd, "Sasanian Art," in The Cambridge History of Iran. The Seleucid, Parthian and Sasanian Periods, ed. Ehsan Yarshater (Cambridge, 1983), 1058-9.

24 Invernizzi "New Archaeological Research in Old Nisa," 8. 


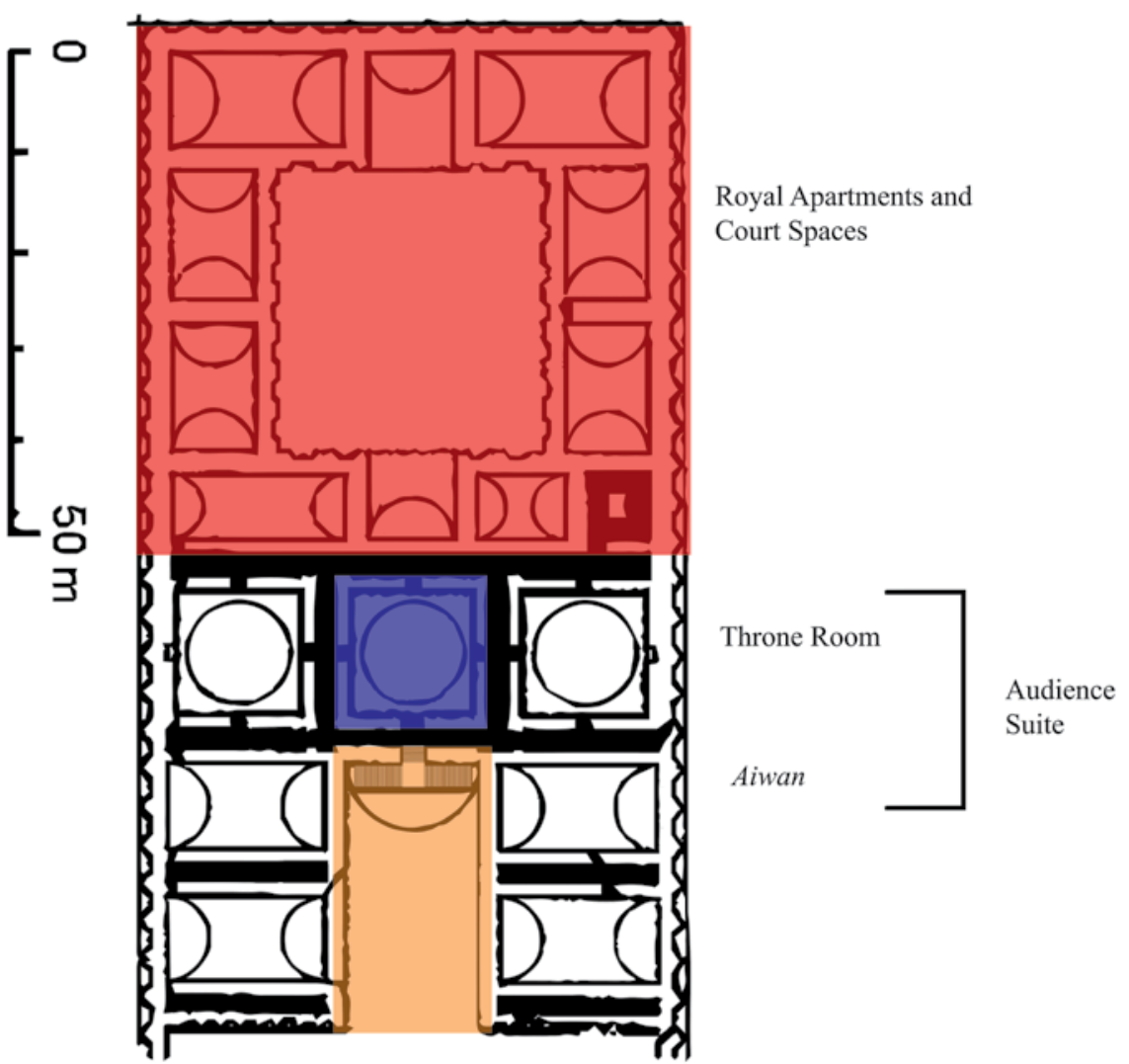

FIGURE 11.7 Plan of the palace of Ardashir I at Firuzabad. Early third c. AD. Demonstrating the organizational layout that became characteristic of early Sasanian palaces. PLAN ADAPTED FROM HUFF 2008.

The palaces of the Sasanian kings were symmetrically and axially conceived, and customarily incorporated a core sequence of rooms arranged along the main axis of the building. This core consisted of a suite of rooms for royal audiences, and a two-story area composed of court spaces on the ground floor and private royal apartments on the upper level. The audience suite preceded the more intimate two-story complex and was made up of an expansive gathering hall with a vaulted ceiling used to house those waiting for an audience, a room known as an aiwan, and an adjoining square room with a domed roof, which served as the throne room (Fig. 11.8). This layout was first formulated in the palaces of Ardashir I from the early part of the third century and became the prototypical configuration for all early Sasanian palaces. ${ }^{25}$

25 Huff, "Qala-ye Dukhtar" p. 127; Huff and Gignoux, "Ausgrabungen auf Qala-ye Dukhtar," 117; Dietrich Huff, "Firuzabad," in Encyclopaedia Iranica vol. 9 (1999, 633-636); Shepherd, 


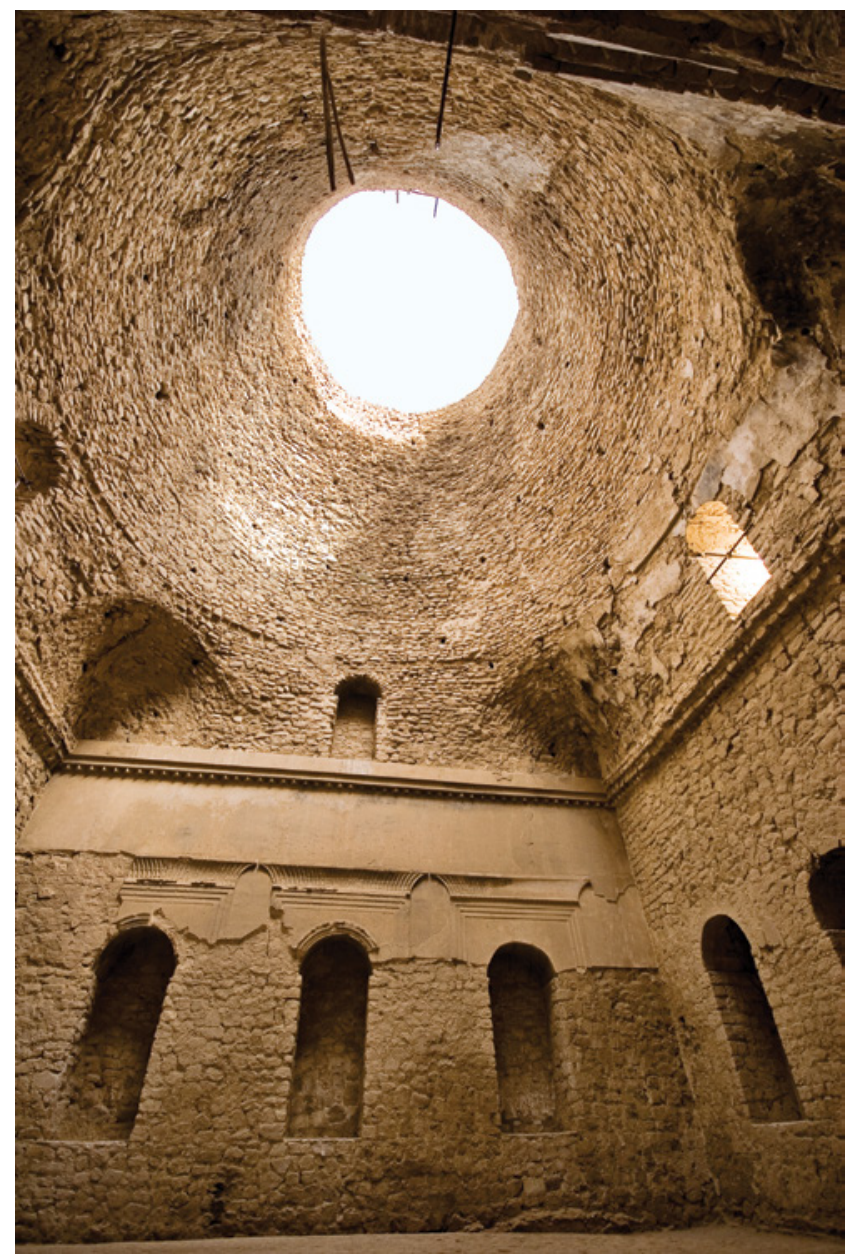

FIGURE 11.8 Throne room at the palace of Ardashir I, Firuzabad. Square room with a domed roof executed in pitched courses of mudbrick.

PHOTOGRAPH COURTESY OF ALI MAJDFAR.

A similar spatial composition is evident at Split (Fig. 11.9). Arranged along the central axis of the southern sector is a progression of spaces associated with royal audiences that serves to preface the more intimate spaces contained in the two-level complex behind. After passing through the tetrapylon located at the crossing of the palace's two main thoroughfares, a visitor would enter a large, slightly sunken, peristyle. Located directly opposite the peristyle

"Sasanian Art," 1058-9; Huff, "Formation and Ideology," 42-4; Huff, "Architecture III: Sasanian Periods." 
entrance from the tetrapylon, the imposing architecture of the protyron, with its temple facade-like appearance and elevated position, dominated the peristyle (Figs. 11.9-11.10). Although not vaulted like the aiwan, the peristyle is believed to have served as a gathering and waiting area for those seeking audience with the emperor, just like its Persian counterpart. ${ }^{26}$

At a level elevated above the peristyle and located directly behind the protyron stands a room with a square footprint enclosed by a brick domed ceiling (Figs. 11.9 and 11.11). The room's function may never be definitively known, but the prominence of its location, the technical complexity of the room shape and its dome mosaic, which was executed with extensive use of expensive

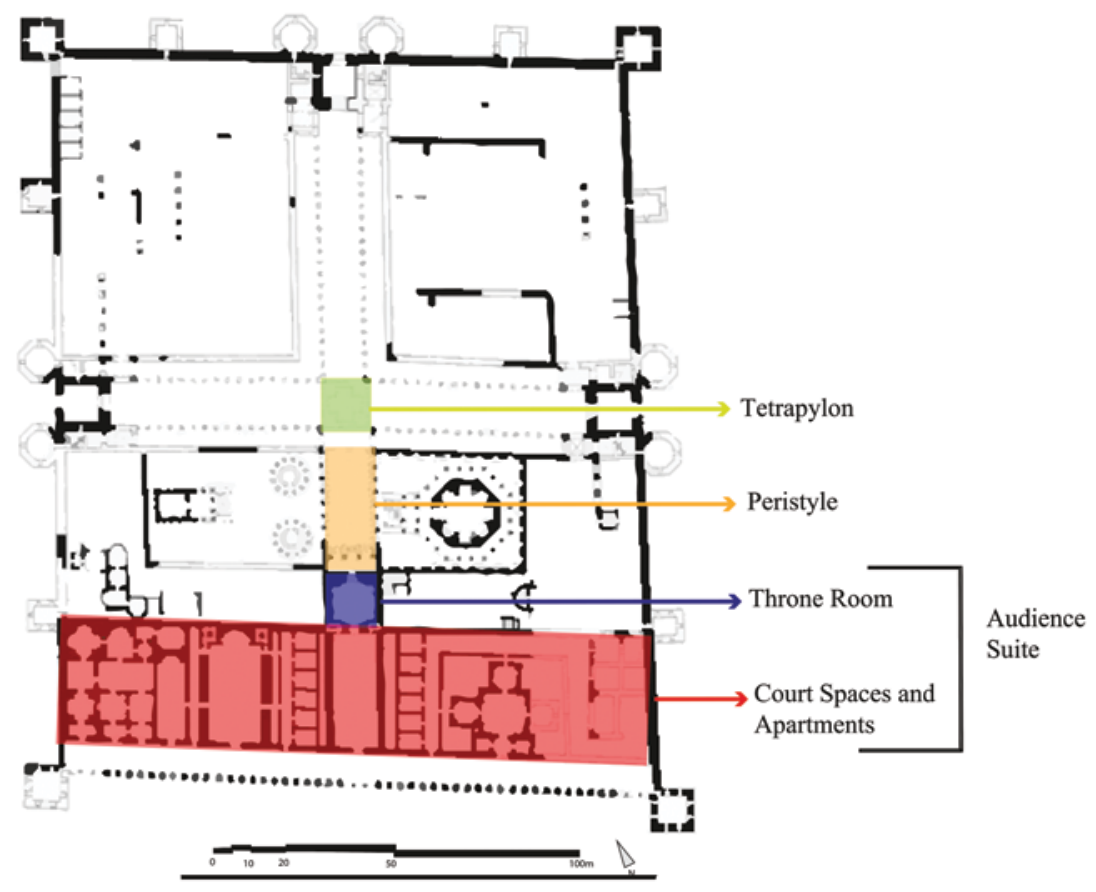

FIGURE 11.9 Plan of Diocletian's palace, Split.

PLAN ADAPTED FROM ĆURČIĆ, 2010.

26 Written sources confirm that important residences including the Palatine were fronted by open-air vestibules intended for use by those awaiting formal admission to the residence; on this point, see Birgitta Tamm, Auditorium and Palatium. A Study on Assembly-Rooms in Roman Palaces During the 1st century B.C. and the 1st century A.D. (Stockholm, 1963), 91-108. The protyron and peristyle probably also played a role in staged court ceremonies, such as at functions related to the emperor's appearances and departures. On this and the peristyle's role as an open-air “waiting room”, see Ćurčić, Architecture in the Balkans, 36. 


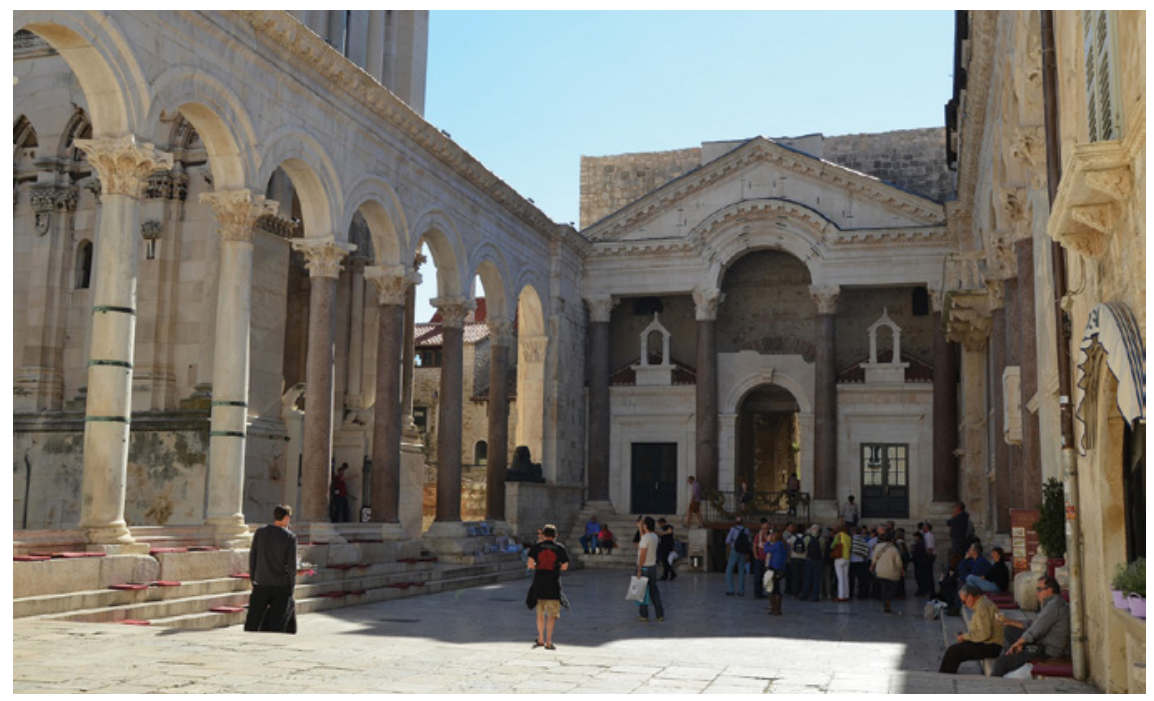

FIGURE 11.10 View through the sunken peristyle to the protyron. Diocletian's palace, Split. PHOTOGRAPH COURTESY OF CAROLE RADDATO, VIA WIKIMEDIA COMMONS/CC-BY-SA.

gold tesserae, ${ }^{27}$ has led to the belief that the room served as a salutatorium or throne room. ${ }^{28}$ If this was indeed the function of the gold-domed room, then there is functional as well as architectural similarity between the rooms on the central axis at Split and those in the Sasanian palaces: both included a vestibule-throne room suite located on the palace's central axis; in both cases that suite provided exclusionary access into the court spaces and royal apartments located beyond in an adjoining two-story complex; and in both cases the throne room consisted architecturally of a square room covered by a brick dome. This last feature is particularly important, given that such a room shape had never before been incorporated into a Roman palace at such a scale and in such a prominent position, although, as stated above, it played a central role as the characteristic shape of the throne room in Sasanian palace design.

Although it is accepted among Sasanian scholars that the imperial residences of the Sasanids were characterized by the proscribed, repetitive plan

27 In fact, this is one of the earliest examples of the use of mosaic on vaults, a decorative feature that would gain particular prominence under the Byzantines; see L. Karaman and F. Bulić, Palača cara Dioklecijana u Splitu [The Palace of Emperor Diocletian at Split] (Zagreb, 1927), 103; Ćurčić, Architecture in the Balkans, 37.

28 Karaman and Bulić, Palača Cara Dioklecijana, 168-70; Ćurčić, Architecture in the Balkans, 37 with previous literature n. 45 . 


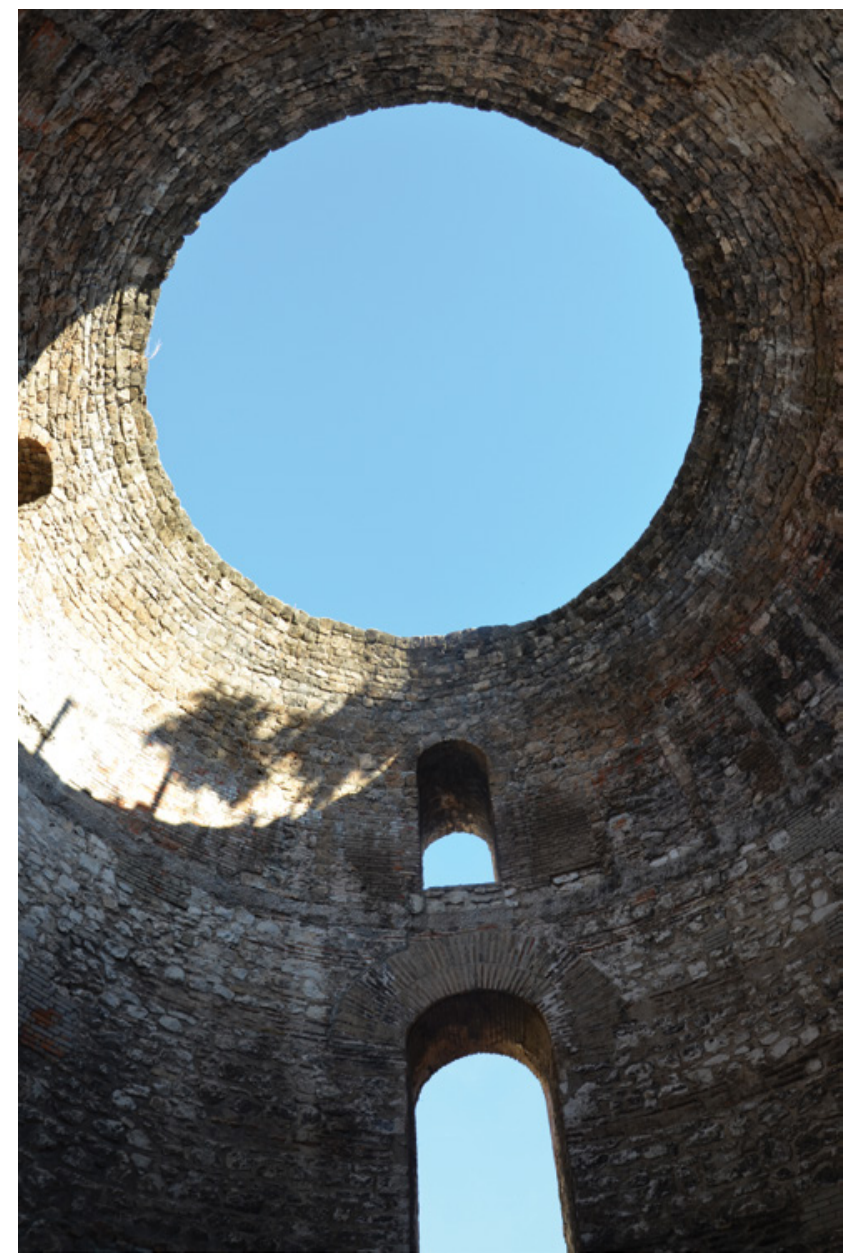

FIGURE 11.11 Domed roof of the 'Throne Room,'Diocletian's palace, Split. Executed in pitched brick technique. PHOTOGRAPH COURTESY OF CAROLE RADDATO, VIA WIKIMEDIA COMMONS/CC-BY-SA.

described for comparative purposes above, this conclusion is based on analysis of early third-century palaces still extant deep within the Sasanian homeland of Persis and the later, sixth-century manifestation of the Ctesiphon palace built atop that city's earlier predecessor. Objection could therefore conceivably be launched against the proposition offered here on the grounds that there is no direct evidence that the Ctesiphon palace of the third century (the palace we are certain members of the Tetrarchy encountered) conformed to the layout now considered characteristic of Sasanian palace structures. It is in this regard 


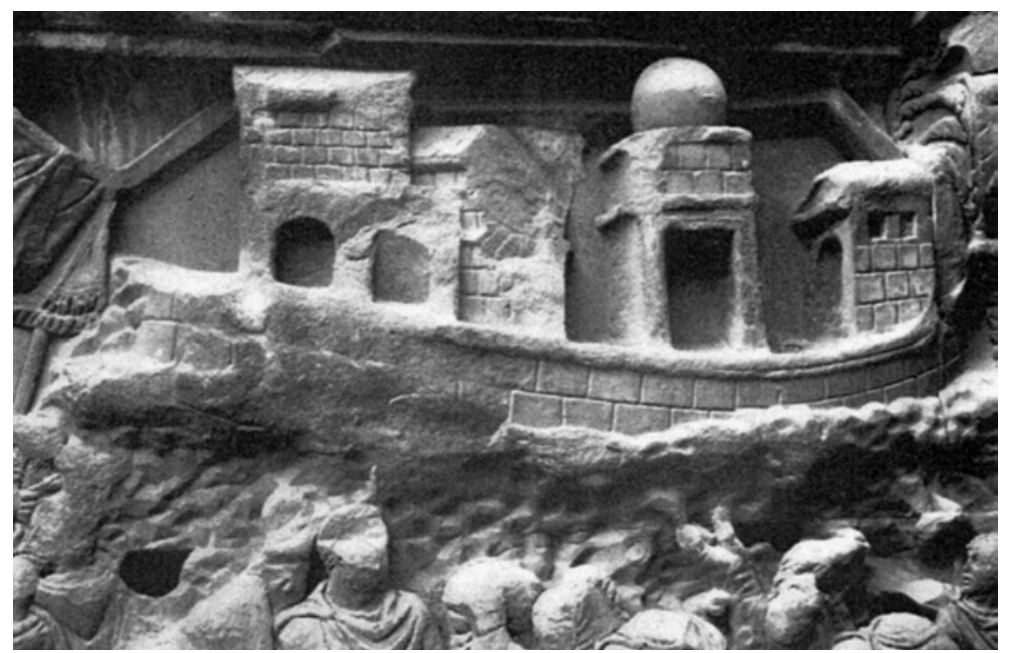

FIGURE 11.12 Depiction of the palace at Ctesiphon. From the so-called Great Historical Panel IV on the southwest side of the Arch of Septimius Severus, Rome. Early third century. After Brilliant 1967, pl. 91 . REPRODUCTION COURTESY OF THE AMERICAN ACADEMY IN ROME.

that the relief representation of the Ctesiphon imperial residence-alluded to above—becomes particularly important (Fig. 11.12). ${ }^{29}$

Appearing on a triumphal monument in Rome as part of a narrative scene depicting Septimius Severus' early third-century capture of Ctesiphon, this summary depiction of the eastern monarch's palace was not intended as a detailed study of the structure. Significant for our purposes are the elements of the structure that are given emphasis in the image as a means of communicating the structure's identity to the Roman audience. Particularly emphasized in this otherwise nonspecific depiction is the walled enclosure that marks off the palace's component buildings, ${ }^{30}$ and, among the cluster of structures

29 This depiction of the palace appears on the southwest so-called "Great Historical Panel IV" of the Arch of Septimius Severus, still standing today in Rome and dated to the early third century. The arch's reliefs summarize Severus' successful campaigns in the east, with panel IV devoted to recounting the Roman army's capture of the capital city, Ctesiphon, which included the looting of the city's imperial palace. For description and discussion of the events and structures depicted in panel IV, see Brilliant, Arch of Septimius Severus, 181-2, 208-17.

30 Significantly, this enclosure wall is not crenelated. In the scene depicted just below on the same panel, the city wall of Ctesiphon is represented with prominent crenelations. The absence of this detail thus differentiates the fortification surrounding the palace from 
inside the enclosure, a building that is carefully distinguished from the others by its conspicuous combination of square footprint and domed roof. The relief image therefore suggests that the palace the Tetrarchs encountered in Ctesiphon exhibited the same distinctive characteristics as the archaeologically investigated Sasanian palaces from Persis used as comparative material in the preceding discussion. ${ }^{31}$

The Roman relief is not only valuable as evidence for the Ctesiphon palace's historical appearance. Conveniently, it is also an indication of what-for a Roman mind-was distinctive in an eastern palace. Schematic architectural rendering depends on the selective depiction of those features the audience is likely to deem a structure's most characteristic elements. The Roman artist's choice to emphasize the very two features that have been identified above as inspirational in the design of Diocletian's palace - that is, the fortification wall and the rectilinear building covered with a dome- suggests that the Tetrarchs knew what they were doing in introducing such elements into their palaces.

The possibility of architectural inspiration derived from the Persian east becomes even more attractive when one considers that the Tetrarchic palaces in the eastern Roman Empire incorporated eastern-inspired constructional techniques and iconographic details previously unattested in the west. The technique used to construct the brick domes mentioned above probably came to the Roman Empire from the east. Domed ceilings constructed entirely out of brick and without the use of centering were unprecedented in Roman imperial architecture prior to the late third century, but were known in Mesopotamia as early as the third millennium вс. ${ }^{32}$ The ubiquity in the east of material

Ctesiphon's city wall and is meant as a signal to the viewer that the group of buildings depicted inside the un-crenelated enclosure is a distinct feature, not another depiction of the city itself. On this point see ibid., 214-5.

31 There is good reason to think that the reliefs on the arch translated into stone (or drew heavily from) the history paintings carried as part of the triumph that followed Septimius Severus' eastern victories. The narrative paintings may have been executed by artists who had been present on the campaigns, thus it is possible the depiction of the palace was based on an eyewitness rendering of the structure. On the reliefs as based on historical paintings, see Susann Lusnia, "Battle Imagery and Politics on the Severan Arch in the Roman Forum," in Representations of War in Ancient Rome, ed. S. Dillon and K. Welch (Cambridge, Eng., 2006). On the spectacle of the Roman triumphal procession and the historical paintings carried therein, see Richard Brilliant, "Let the Trumpets Roar!' The Roman Triumph," in The Art of Ancient Spectacle, ed. B. Bergmann and C. Kondoleon (Washington DC, 1999), 221-229; Mary Beard, The Roman Triumph (Cambridge, Massachusetts, 2007), 143-86.

32 Bernard O'Kane, “Domes," in Encyclopaedia Iranica vol. 7 (1995), 479-485; O. Reuther, "Sasanian Architecture, A History," in Survey of Persian Art, ed. A. Pope, (London, 1938), 501. On the related technique of pitched brick curved vault construction imported to the Roman Empire from the east at an earlier date, see Lancaster, "Parthian Influence.." 


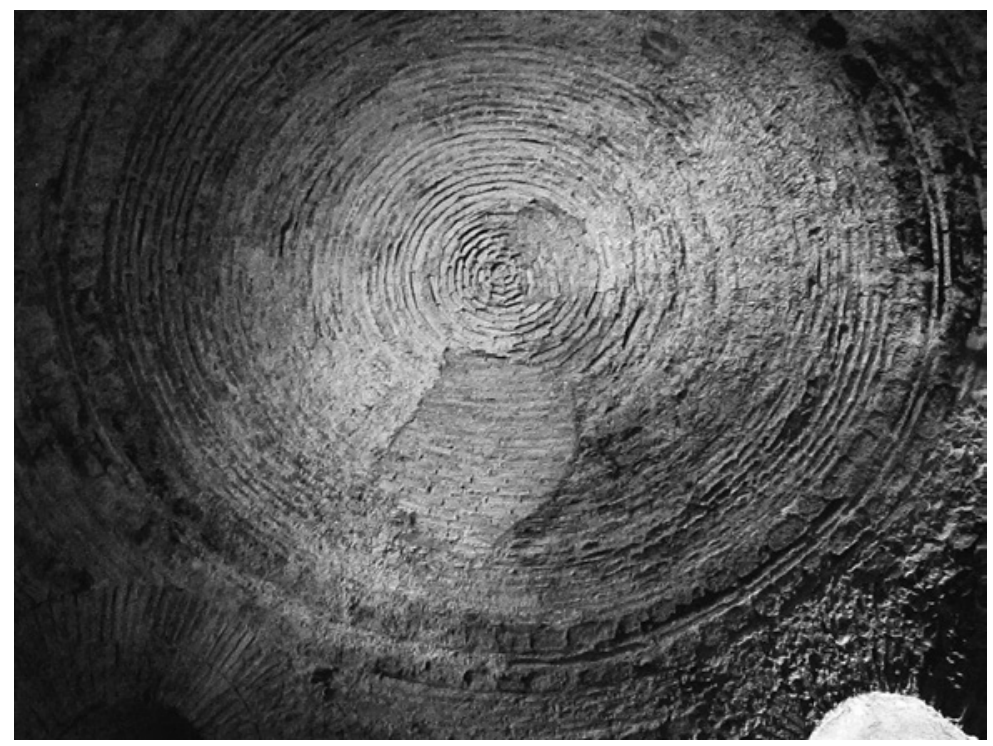

FIGURE 11.13 Pitched brick dome in a basement room of the residential apartments, Diocletian's palace, Split. The technique of executing domes with pitched courses of brick is unknown in imperial architecture before the Tetrarchic period and probably came to the Roman Empire from the east. AUTHOR'S PHOTOGRAPH.

for brick-making relative to stone and wood led to the development of this technique for dome construction. ${ }^{33}$ Pitched brick domes still stand today in Split's mausoleum, the domed throne room located directly behind the protyron, and in two rooms in the basement level of the palace's residential apartments (Figs. 11.11 and 11.13).

If, on analogy with Romuliana, it is assumed that soldiers were responsible for the construction of the palace at Split, it is not hard to imagine how such a constructional technique came to be introduced in the Roman Empire. Architects and engineers routinely traveled with the Roman troops, ${ }^{34}$ and as stated above, the very troops who built Romuliana were those who traveled in the preceding

33 Construction of domes from concrete or stone required the use of wooden centering. Brick domes, due to the relative levity of the material, required very little, if any, centering. See Ćurčić, Architecture in the Balkans, 40.

34 Appollodorus of Damascus, architect of Trajan's bridge over the Danube during the Dacian Wars of the early second century, is perhaps the most well known of the architects who travelled with the Roman army. On Appollodorus of Damascus, see P.H. Blyth, "Apollodorus of Damascus and the Poliorcetica," Greek, Roman, and Byzantine Studies 33 (1992), 127-158. 
years with emperor Galerius on his Persian mission. It is very much possible, therefore, that Galerius' imperial colleague (who had himself had experience in Persia) employed architects and engineers in the construction of the residence at Split who had firsthand experience of architecture in the rival realm.

Written sources and corroborating archaeological evidence also provide reason to think that forced deportations of war prisoners may have played a part in facilitating the exchange of ideas, technologies, and customs with enemy territories. In the course of the third-century conflicts between the Roman and Persian Empires, sources testify that both powers were responsible for the forced resettlement of thousands of their captured enemies within their own territories. ${ }^{35}$ Meanwhile, excavations and stylistic studies at the Sasanian site of Bishapur, a city built de novo by Shapur I as a sort of victory monument after his decisive mid-third century victory over the Romans at Edessa, point to the likelihood that captured Romans were among the workforce deployed in the construction of the city. ${ }^{36}$ Since it is certain that the Romans, like their Persian counterparts, subscribed to the practice of resettling foreign

35 Shapur I claims in his monumental inscription at Naqsh-i Rustam that he took prisoner a great number of Roman soldiers, generals, and high ranking elites after his victory at Edessa, and deported these individuals into the territory of Persis. In the same inscription, he also states that he deported Roman men from the cities he captured during his campaign and resettled them in the Persians' territories in Persis, Parthia, Khuzistan, and Babylonia. For an English translation of the inscription, see M. Sprengling, "Shahpuhr I, the Great on the Kaabah of Zoroaster (KZ)," American Journal of Semitic Languages and Literatures 57 (1940), 341-429, especially lines 11-16. For their part, the Romans enforced similar resettlements for the inhabitants of cities that they captured in the third and early fourth centuries. The panegyric delivered at Trier in honor of Constantius I in 297 CE records that Diocletian deported colonies of prisoners from Asia into Thrace. See Panegyrici Latini virı.21.1. Slightly later, Libanius mentions in an encomium for the emperor Constantius II (r. 337-61 CE) that the Romans captured a number of Sasanian cities in the course of war with the Persians and removed their populations to Thrace. See Libanius, Oration 59.83-4. For discussion of deportations as a source for transfer of artistic ideas between east and west, see Canepa, Two Eyes of the Earth, 27-29.

36 For the orthogonal plan of Bishapur and its connection with Roman military camp design, see Dignas and Winter, Rome and Persia (see above, n. 1), 254-7. For analysis of the decorative plasters, mosaics, and use of ashlar masonry at Bishapur and their connection to Roman craftsmen, see Canepa, Two Eyes of the Earth, 75-78; Edward J. Keall, "Bisapur" Encyclopaedia Iranica, 16 vols. (1989) IV: 287-289; Roman Ghirshman, Iran from the Earliest Times to the Islamic Conquest (Harmondsworth, 1978), 140-9; Hubert von Gall, "Die Mosaiken von Bishapur," Archäologische Mitteilungen aus Iran IV (1971), 193-206; Roman Ghirshman, Fouilles de Châpour. Bîchâpour, 2 vols. (Paris, 1971) 2:38-148; Shepherd, "Sasanian Art," 1064-5 and 1075; Georges Salles, "Nouveaux documents sur les fouilles de Chapour, IV ${ }^{\text {me }}$ et Vme campagnes," Revue des arts asiatique XIII (1939-42) 98. 
populations within their own territory after conclusive military interventions (such as those leading up to the Treaty of Nisibis), it is conceivable that just like the contemporary practice in Persia, the Roman administration may have selected skilled individuals from among their captured and displaced enemies to work on imperial projects in Roman territories. Such practice would have held both practical and ideological weight and would certainly account for the introduction of a Mesopotamian building technique at Diocletian's palace.

Taken all together then, comparison between the late Roman palace at Split and Sasanian royal residences reveals a confluence of conceptual similarities and other physical evidence that suggest that contact and competition with the Persian empire in the latter part of the third century may account for the novelties observable in the non-urban Tetrarchic palatial architecture described above. The idea to experiment with the concept of a walled palace may have been spurred by contact with the Persians, even though aesthetically the concept is executed at these late Roman palaces in Greco-Roman formal vocabulary. Bolstering this argument is the similarity in both form and function of a specific, axially aligned and compact system of rooms in both the eastern and western palaces; further, in both cases, among this system of rooms was a prominently placed square throne room with domed roof executed in the Mesopotamian-derived pitched-brick building technique. That the construction technique and the use of such a room shape at this scale is unparalleled in Roman palace design, along with the prominence of these two features in Sasanian palaces dating slightly prior to the Tetrarchic examples strengthens the argument for palatial cross-fertilization at the end of the third century.

\section{4 Co-Opted Iconography: The Equestrian Duel}

Architecture was not, however, the only medium to see borrowings from the Persian east under the rule of the Tetrarchy. It was under Tetrarchic reign that a characteristically Persian iconography, that of two mounted main combatants engaged with one another in military confrontation, made its first appearance on a Roman imperial monument. ${ }^{37}$ Prior to this time, a number of imperial monuments envisioned the mounted Roman emperor taking a leading role in combat against the enemies of Rome regardless of whether he was actually known to have participated in the melee portrayed (Fig. 11.14). In the long history of such motifs in the Roman Empire, however, no Roman monument ever featured the mounted emperor in battle with an enemy on horseback—none, that is, until the Arch of Galerius in Thessaloniki (Fig. 11.15). 


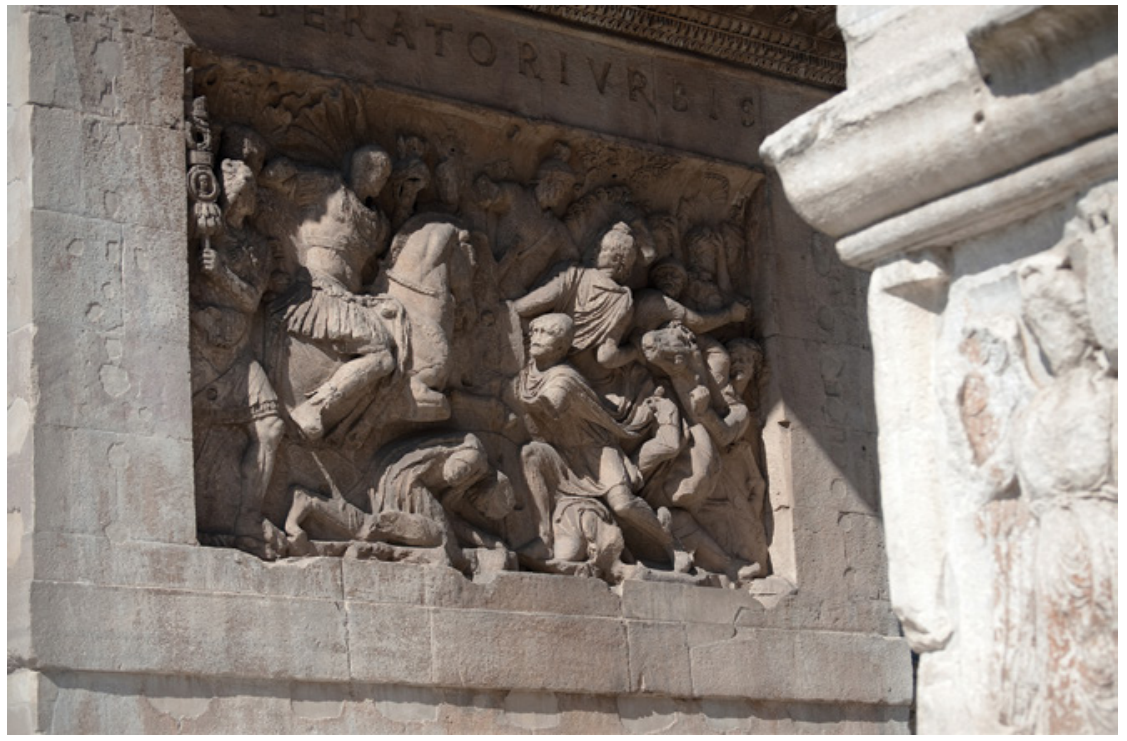

FIGURE 11.14 Great Trajanic Frieze, 2nd c. AD, reused on the Arch of Constantine, Rome.

(C) THE TRUSTEES OF COLUMBIA UNIVERSITY, MEDIA CENTER FOR ART HISTORY, DEPARTMENT OF ART HISTORY AND ARCHAEOLOGY.

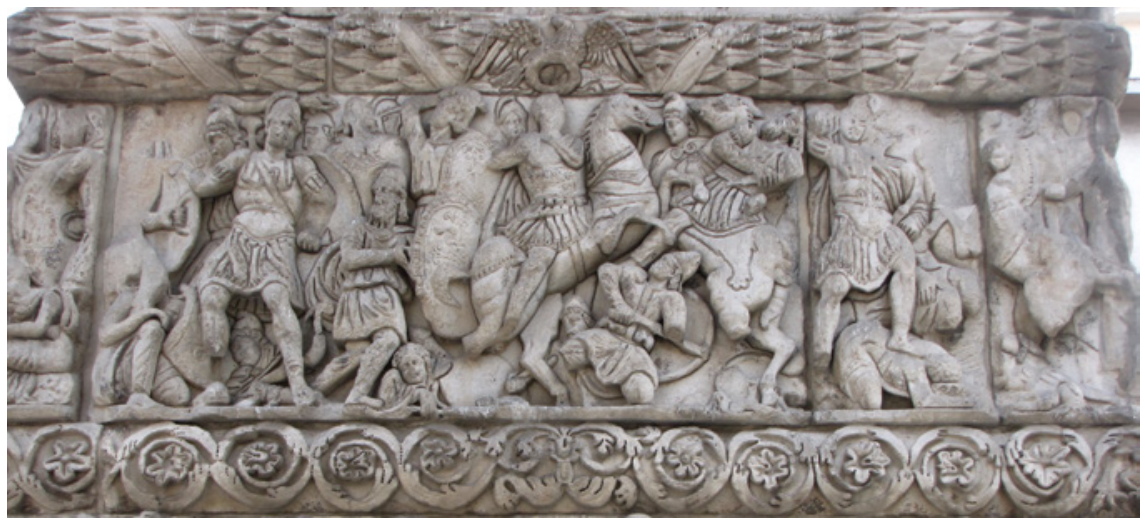

FIGURE 11.15 Equestrian duel relief. Arch of Galerius, Thessaloniki. AUTHOR's PHOTOGRAPH.

Placed conspicuously at the exact center of the relief composition, Galerius sits astride a charging horse. Both horse and emperor are outfitted with fine trappings befitting Galerius' status as Roman ruler. And while the figure of the Roman emperor is undoubtedly marked out as the focus of the scene, he confronts another figure, placed just to the right of the frieze's central axis, who is comparably mounted on the same groundline as the emperor and depicted 
as his equal in stature. On account of this egalitarian portrayal, the opponent, dressed in trousers and using a pantherskin as a horse blanket, is identified as Narses, king of the Sasanians. In his campaigns against the Sasanians Galerius never actually engaged in battle with the Sasanian king, and thus this vignette serves to visually panegyrize the emperor's virtus just like the reliefs of old, but this time using the new format of the equestrian duel.

What is important for our purposes is that although the imagery of an equestrian duel between ruler and opponent was new to the Roman repertoire, and lacked Hellenistic parallels as well, it had a history in Persian iconography both on monumental reliefs (Fig. 11.16) and on small, transportable objects (Fig. 11.17). ${ }^{38}$ Even more importantly, the composition had a history of being used to the detriment of Roman imperial reputation. The years leading up to the foundation of the Tetrarchy had seen a series of catastrophic military clashes against the Sasanians that resulted in repeated sackings for the Romans, as well as what was possibly the single greatest disaster the imperial Romans had ever suffered at the hands of an enemy - the first and only enemy capture of a Roman emperor. Capitalizing on his successes against the

38 The iconography of an equestrian duel between king and challenger seems to have been uniquely Iranian, with no Hellenistic precedent, and certainly no precedent in statesponsored Roman monumental art. The closest western parallel is the famous mosaic floor depicting Alexander's triumph over Persian opponents from the House of the Faun in Pompeii, dated to the second century вс but commonly presumed to be a copy after a Hellenistic painting. However, two important differences separate the mosaic's iconography from the Iranian equestrian duel imagery considered here, and thus the iconography preserved in the mosaic should not be seen as a Hellenistic precedent for the Parthian and Sasanian compositions. Whereas in the Iranian compositions king and challenger confront one another head-on, Darius III is portrayed running away from the battle by chariot. The Hellenistic composition thus robs the Persian king of any heroism, in stark contrast to the valorizing effect of the Iranian imagery. Also important is the fact that Alexander, though depicted as an active participant in the battle, is not militarily engaged with king Darius, but rather with one of the Persian foot soldiers. Although the post-Seleucid Persian dynasties and Romans alike were impacted by their exposure to Hellenistic iconographies, in this case the composition of two enemy rulers confronting one another in an equestrian duel is without comparable Hellenistic precedents. Therefore, the similarity between the equestrian relief from the Arch of Galerius and Sasanian equestrian imagery may not be explained as a case of Romans and Sasanians evolving similar iconographies from a common Hellenistic prototype. On the history of the equestrian duel iconography in Parthian and Sasanian art, see Canepa, Two Eyes of the Earth, 68-71; Hubertus Von Gall, Das Reiterkampfbild: in der iranischen und iranisch beeinflussten Kunst parthischer und sasanidischer Zeit (Berlin, 1990). On the Alexander Mosaic from the House of the Faun, see recently Ada Cohen, Art in the Age of Alexander the Great: Paradigms of Manhood and their Cultural Traditions (Cambridge, 2010), 162-70. 
Romans, the Sasanian king took the opportunity in the later part of the third century to assert his own status by propagating an unflatteringly impotent visualization of Roman power. ${ }^{39}$ It is in this respect that the equestrian duel imagery was put to use against the Romans. A cameo today in Paris portrays the capture of the emperor Valerian as a mounted battle between the Roman ruler and the Sasanian king (Fig. 11.17).40

Although situated on an undeniably Roman style monument and embedded amongst traditionally Roman visual tropes - such as the compositional device familiar from imperial monuments and sarcophagi of staging bodies on high, middle and low visual planes to suggest the chaos of war; or the triumphant soldier treading upon a fallen enemy in a favored pose of Roman dominance-apparently the equestrian duel relief from the Arch of Galerius was intended to respond to its Persian model. ${ }^{41}$ The Tetrarchs' own Persian campaigns were predicated on the reassertion of Roman power in the East and

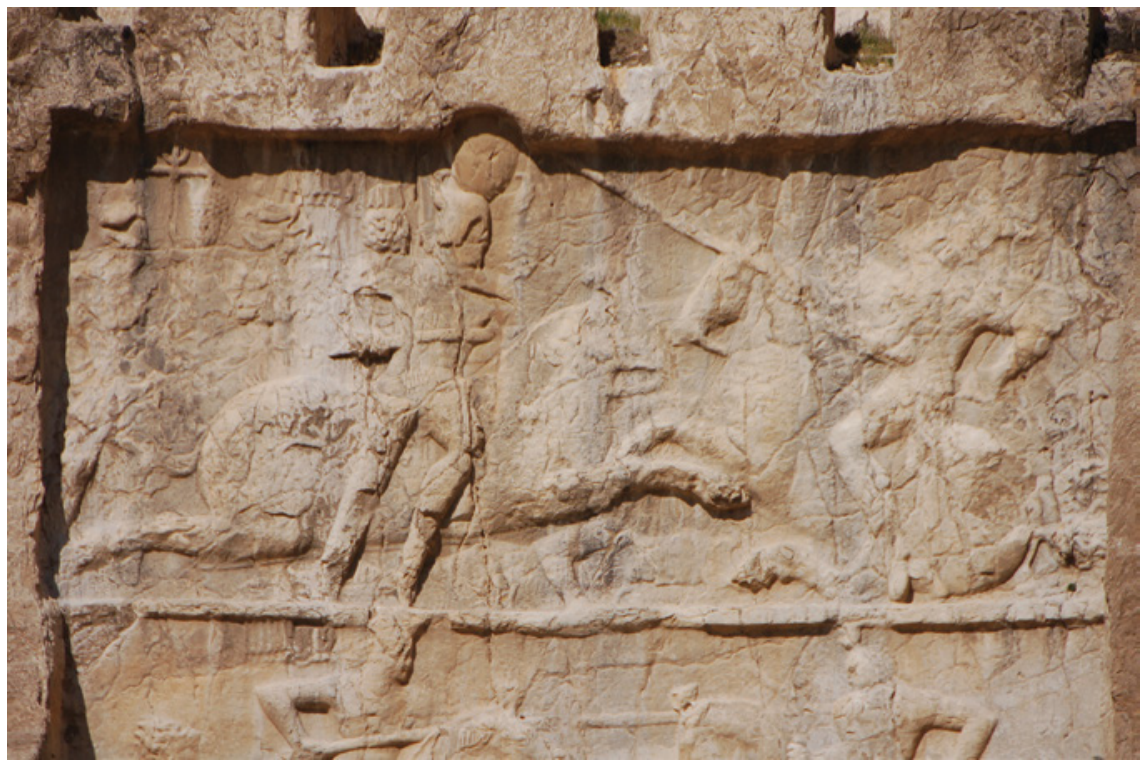

FIGURE 11.16 Equestrian duel between Sasanian King Bahram II and a challenger, bas relief from Naqsh-i Rustam. Third century AD.

PHOTOGRAPH COURTESY OF HELEN EVANS.

39 On Sasanian efforts to propagate an unflattering image of Roman power in the third century and Roman response to the provocation, see Canepa, Two Eyes of the Earth, pp. 53-99.

40 For recent discussion of the cameo and its connection to the equestrian duel imagery used on the Arch of Galerius, see ibid., 68-71, 93-94.

Ibid., 93-94. 


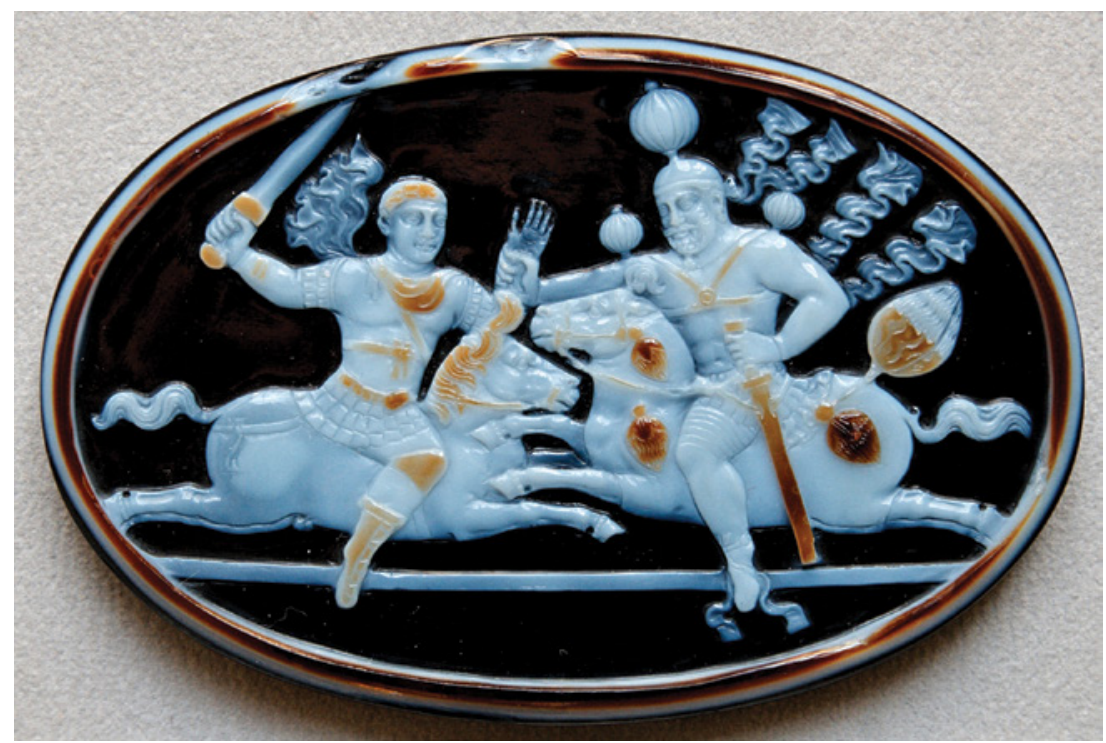

FIGURE 11.17 Sardonyx cameo featuring the Sasanian King of Kings capturing Emperor Valerian. Bibliotheque Nationale de France, Cabinet des médailles, inv. Babelon 360 . PHOTOGRAPH COURTESY OF MARIE-LAN NGUYEN, VIA WIKIMEDIA COMMONS/CC-BY.

the need to right the wrongs of the preceding years. ${ }^{42}$ It was a poignant choice to make use of this iconography at the historical moment when the balance of

42 There is good evidence that the mid-century Sasanian victories were still palpable, raw, and a motivating factor in Roman foreign policy even at the end of the third century. On the motivation for emperor Carus' campaign against the Persians, in which Diocletian and probably Maximan took part, see Anonymus post Dionem, Fragmenta Historicorum Graecorum 4, 198, frag. 12. In the end, the unexpected death of Carus at the height of the campaign caused the Romans to abandon what had been a very successful foray into Persian territory, therefore leaving the mission of absolute Persian disgrace frustratingly incomplete. The preamble to the Edict on Maximal Prices issued by the Tetrarchy in $301 \mathrm{AD}$ and Peter the Patrician's sixth-century account of Galerius' peace negotiations with a Persian ambassador in $298 \mathrm{AD}$ (written with access to imperial archives) both point to the Tetrarchic continuation of a deep-seated imperial drive to avenge the wrongs the Sasanians had perpetrated against the Romans. For a translation of the preamble and the list of prices, see Naphtali Lewis and Meyer Reinhold, eds. Roman Civilization. Selected Readings Edited with an Introduction, vol. 2 (1955), 464-72. For Peter the Patrician's account of the motivating factors for war between the Tetrarchs and the Sasanians, see Geoffrey Greatrex and Samuel N.C. Lieu, eds. The Roman Eastern Frontier and the Persian Wars. Part II, AD 363-63o: A Narrative History (London, 2002), 132. 
power had tipped back in Roman favor. In adopting and repackaging a Sasanian iconography in the context of a thoroughly Roman depiction of battle, the Romans turned on its head the same iconography that not long before was used to imply Rome's subjugation to the Sasanian king.

Embedding this borrowed iconography on the Thessaloniki arch not only conveyed Galerius' defeat of Narses, but also his success in defeating the Sasanian king at his own game, in his own visual vocabulary of military dominance. The Roman emperors and Sasanian kings of the third and early fourth centuries were locked in an international contest that pitted each ruler's conflicting claims to world supremacy against those of his challenger. In a clash such as this, rulers needed to make their assertions of power, strength, and ultimate supremacy legible not only to their own subjects, but also to the ruler and subjects of the enemy territory. ${ }^{43}$ Using this typically Sasanian iconography emphasized that, at long last, Galerius had literally reversed the fortunes of the Romans in their struggle against their eastern neighbors, and it did so in a visual idiom that was legible to both Romans and foreigners alike.

\section{Diocletian's Palace in a New Light}

Tetrarchic fortified palaces, including Diocletian's palace in Split, can almost certainly be understood in this same light. Both the borrowed iconography and the architectural similarities appeared in Roman dominions at the same time - that is after decisive Roman defeat of their Sasanian enemies in the late 29os AD. Like the co-opted iconography, architectural reference to Sasanian models served the dual purpose of 'cultural booty' on the one hand, and on the other, functioned to extend the legibility of the Roman emperor's propaganda to a wider, more international audience. ${ }^{44}$ In support of this latter point, it is striking that these adopted ideas were not put to use haphazardly, but rather strategically used in palaces, that is, contexts that international observers, be they kings, emissaries, high-ranking hostages or ambassadors, could be expected to encounter. ${ }^{45}$

\footnotetext{
43 Canepa, Two Eyes of the Earth, 1-5.

44 Ibid., 1-5, 21-22.

45 For a general discussion on the topic of Romano-Persian diplomacy and the exchange of ambassadors, see Dignas and Winter, Rome and Persia, 245-54. On its more specific implications for the exchange of ideas between the Roman and Sasanian empires and the viewership of the Arch of Galerius, see Canepa, Two Eyes of the Earth, pp. 30-31, 96. Ammianus Marcellinus writes that in the case of the treaty between Shapur II and Jovian,
} 
In fact, written sources of the period suggest that Persian presence at the Roman court in the third and fourth centuries was by no means unusual, thus the ideological impact of the elements the Romans borrowed from the east would have been readily legible to an important part of the population who encountered them. The relief representation of the eastern palace at Ctesiphon from Severus' arch in Rome, and the triumphal paintings on which it may have been based, ${ }^{46}$ on the other hand, remind us that Persians were likely not the only ones capable of reading the significance of Split's foreign architectural referencing. The Severan relief's summary architectural rending suggests that for the diverse audience in the city of Rome it was a fortification wall marking off a group of component buildings and a prominently placed, square footprinted building with a domed roof that were the most readily identifiable elements of a Persian palace. Thus the placement of Diocletian's palace inside its own walled enclosure and the use of the distinctively shaped and organized audience suite at Split may indeed have been legible to individuals from a variety of backgrounds within Roman territory.

With a legacy of embarrassing defeats at the hands of the Sasanians in the third century, the Tetrarchs needed to both redress the image of Roman power propagated by the Sasanians and self-fashion a counter-image that adequately competed with that of the eastern rival who had so recently held the upper hand. The Roman emperors' selective import, adaptation, and repackaging of aspects gleaned from the court of their Sasanian neighbors served exactly this purpose ${ }^{47}$ In forwarding this thesis, it is important to note this was not the first time that after a significant victory the Romans co-opted and redeployed architectural features originating in a culture they deemed a

the Romans and Sasanians both sent groups of high ranking elites to the court of the other to act as hostages; these individuals were intended to serve as collateral ensuring that both sides would keep to the terms of the peace contract. See Ammianus Marcellinus 25.7.9-14. Although there is no comparable source definitively stating that the Romans and Sasanians arranged for a similar exchange of elites in the Tetrarchic period, the idea is at least conceivable given that the two powers completed the major diplomatic Treaty of Nisibis in 298/9 AD. Whether or not long-term hostages were held at the Roman court following the peace with Narses, it is undeniably the case that the Romans held the Persian harem and a group of Persian nobles for a period of time following the Romans' decisive 298 AD victory at Satala. For the capture of the harem, see Eutropius, Breviarium, 9.25; Festus, Breviarium. 25; Petrus Patricus, frag. 13-14.

$46 \quad$ See above n. 31.

47 Canepa, Two Eyes of the Earth, 21-22, 53-99. 
decadent 'Other' —one need only look to Augustan Rome following the Battle of Actium for parallels. ${ }^{48}$

Roman emperors could borrow from the enemy when it suited their purposes, but this had to be done with care. In every case, the features the Romans chose to adopt from Persia were those that had relevance within their new Roman setting and blended easily with elements of an established Roman pedigree so as not to openly announce their foreign extraction. At Split, the idea to establish a fortified palace may have been transferred from the east, but the walls and military-inspired features that enclosed the complex were Roman in style. Likewise, for all its conceptual, organizational similarity with Sasanian palaces, all of the constituting features in Diocletian's palace were translated into decisively Roman architectural terms - perhaps most conspicuously, a peristyle courtyard took the place of the typically Sasanian aiwan. Such design allowed those critics who might otherwise have taken objection to imperial adoption of foreign elements or practices within the Roman realm to conveniently overlook them.

The blinkered view of the Late Antique world shaped by culturally-isolationist disciplinary trends is finally in retreat. The parallels illustrated here between Roman and Sasanian palatial architecture introduce not only a new way of viewing Diocletian's palace at Split, but also a new way of understanding Late Antique palace design as an ingredient in the negotiation of power relationships between Rome and her enemies. As part of an ever-advancing field, new discoveries and methodologies should always call us to reevaluate, revise, and expand the conclusions we draw from even those monuments deeply etched in the historical canon.

48 On the horologium of Augustus and the general use of obelisks in Augustan Rome as cultural booty signaling the Roman victory at Actium, see Molly Swetnam-Burland, "Aegyptus Redacta: Augustus' Obelisk in the Campus Martius" Art Bulletin 92, no. 3 (2010), $135^{-153}$. 